\title{
PROGNOSTIC VALUE OF COMBINED IMMUNOHISTOCHEMICAL EXPRESSION OF BMI1 AND EZH2 IN ASTROCYTOMA
}

\author{
Lobna Abdelaziz Abdelsalam, Yehia Elalfy Ali, Kamal Ahmed Elkashishy, Eman Taher Nour Eldeen \\ Department of Pathology, Faculty of Medicine, Zagazig University, Egypt
}

Corresponding author:

Lobna Abdelaziz Abdelsalam, e.mail:dr.lobna2013@yahoo.com

\begin{abstract}
Background: Although current improvements in surgery, chemotherapy and radiotherapy, the still survival of astrocytoma's patient is poor. It is assumed that the combined expression of BMI1 and EZH2 may be associated with malignant transformation of astrocytomas and also it may reveal the biological aggressiveness of this disease.

Aim of work: assessment the value of the combined immunohistochemical expression of BMI1 and EZH2 and their correlation with the clinicopathological characters and prognosis in astrocytoma patient.

Subjects \& Methods: BMI1 and EZH2 expressions were evaluated using immunohistochemical staining in 70 patients 40 cases with astrocytomas and 30 cases of non-neoplastic brain tissue. The relationship between their expressions and clinicopathological factors were analyzed.

Results: A significant difference $(\mathrm{P}<0.002)$ between expression of BMI1 and EZH2 in astrocytoma compared to corresponding non-neoplastic brain tissue. A significant association was found between high expression of BMI1 and EZH2 and WHO high grades in astrocytomas. No statistically significant association was found between BMI1 or EZH2 with gender of patients, age at diagnosis, site and size of tumor $(\mathrm{P}>0.05)$. The spearman correlation analysis revealed a significant positive association between BMI and EZH2 expressions $(\mathrm{r}=0.311 ; \mathrm{P}=0.05)$ revealing direct relationship between BMI1 and EZH2.

Conclusions: BMI1 and EZH2 were involved in astrocytoma malignant transformation and poor prognosis in astrocytoma particularly glioblastoma.

Keywords: BMI1, EZH2, astrocytoma, PcG, glioblastoma and GSCs.
\end{abstract}

\section{INTRODUCTION}

A lthough current improvements in surgery, chemotherapy, and radiotherapy, still the survival of astrocytoma's patient is low. Astrocytic tumors include; pilocytic astrocytoma [World Health Organization (WHO) grade I but pilomyxoid type is grade II], subependymal giant cell astrocytoma [WHO grade I] diffuse astrocytoma [(fibrillary, gemistocytic, and protoplasmic types), pleomorphic xanthoastrocytoma, WHO grade II], anaplastic astrocytoma [WHO grade III] and glioblastoma (giant cell glioblastoma, gliosarcoma and gliomatosis cerebri) [WHO grade IV] ${ }^{[1]}$. The prognosis of a given fibrillary astrocytic neoplasm is a complex function of both clinical and morphologic variables [1]. Particularly, the prognosis of glioblastoma multiform (GBM) patients has not changed considerably for decades, revealing median survival less than one year ${ }^{[2] .}$ GBM comprises functional groups of cells called glioblastoma stem-like cells (GSCs) that are radioresistant and chemoresistant and are involved in tumor recurrence ${ }^{[3] .}$ Glioblastoma stem-like cells exist in a niche around arterioles that protects these cells from therapy by maintaining a somewhat hypoxic environment ${ }^{[4]}$.

\section{PcG Proteins role in cancer}

Polycomb group (PcG) proteins are considered as transcriptional inhibitors, regulating many vital cellular physiological and developmental processes and playing essential roles in carcinogenesis $^{[5] .}$ Dysregulation of polycomb group $(\mathrm{PcG})$ proteins (including BMI and 
EZH2) are closely related to the glioblastoma stem-like cells maintenance and tumorigenicity [3]. PcG proteins suppress gene expression selectively by development of multi-subunit complexes called polycomb repressive complexes (PRCs), regulating chromatin organization, maintaining it transcriptionally inactive [5]. The PRCs essentially comprise PRC1 (including BMI1) and PRC2 (including EZH2). Both PRC1 and PRC2 make covalent post-translational histone alterations [6]. Abnormal PcG expression or mutations falsely activate proto-oncogenes, resulting in loss of cell character, with sustained ability of proliferation, resistance to apoptosis mechanisms, and escape of cellular senescence programs, increased migratory and invasive ability, cancer stem cells maintenance and generation [7]. Numerous PcG proteins reveal diverse expression in malignant tissue in comparison to conforming non neoplastic tissue [8]. Not only abnormal levels of PcG proteins are found in human cancers but also many missense mutations and chromosomal translocations [9]. BMI1 and EZH2 furthermore inhibit tumor suppressor genes like phosphatase and tensin homolog (PTEN), consequently activating the phosphoinositide 3-kinase (PI3K)-Akt-glycogen synthase kinase $3 \beta$ (GSK3 $\beta$ ) pathway and promoting the EMT (epithelial-mesenchymal transition) and invasion [10]. Abnormal expression of EZH2 leads to genomic instability and consequent malignant transformation ${ }^{[11] \text {. }}$

\section{BMI1 role in cancer}

BMIloverexpression played a vital role in several types of cancer, for example bladder, skin, prostate, breast, ovarian, colorectal and mantle cell lymphomas ${ }^{[12] . ~ B M I 1 ~ i n h i b i t s ~ M y c-~}$ induced apoptosis by suppression of the cyclindependent kinase inhibitor locus, encoding ARF and INK4 proteins, both of limit proliferation of cells in response to abnormal mitogenic signaling [13]. BMI1 overexpression expects poor prognosis and advanced disease in numerous human cancers ${ }^{[8] .}$ The expression of BMI1 is frequently linked to aggressive and stem cell-like chemoresistant cancers as prostate cancer ${ }^{[14]}$, head and neck cancer ${ }^{[15]}$, pancreatic adenocarcinoma [16]. However, BMI1 overexpression may not associated with a poor prognosis for all types of cancer, as BMI1 high expression are related to a improved survival in breast cancer, malignant melanoma and endometrial carcinomas patients ${ }^{[8]}$

BMI1 high expression predicts metastases in precancerous tissues and biopsies, thus acting as an invaluable diagnostic tool as in precancerous gastrointestinal tract lesions ${ }^{[17]}$. BMI1 overexpression is related to dysplastic transformation of cells in oral carcinogenesis, essential for cancer cell maintainance and proliferation [18]. In renal carcinoma, BMI1 expression is correlated inversely with carcinoma grade, acting as a marker of differentiation, which is lost in carcinomas of high grade ${ }^{[19]}$.

BMI1, regarding progression of cancer, depends on the type of tumor cell so it necessity to be considered when developing targeted new plans for therapy ${ }^{[8] \text {. }}$

\section{$\mathrm{EZH} 2$ role in cancer}

EZH2 is not expressed normally in healthy adults but it is only present in actively dividing cells, as those active during fetal development [20]. EZH2 is expressed in a many human cancers, associating with tumor aggressiveness through all types of cancer [8]. EZH2 is upregulated in multiple cancers including breast [21], and human prostate cancer, especially hormone-refractory prostate cancers [22]. Somatic EZH2 deletions and mutations, inhibiting the activity of EZH2 methyltransferase are present in follicular lymphomas, B cell lymphomas, myeloproliferative and myelodysplasic disorders ${ }^{[23] .}$ In glioblastoma multiform, EZH2 hinders differentiation and activates genes regulating cell cycle progression, cell proliferation, and cell migration [24]. $\mathrm{EZH} 2$ is supposed to involve the senescence program in malignant cells owing to the transcriptional suppression of the INK4b-ARF-INK4a locus $[13]$.

MATERIALS AND METHODS Patients and tissue specimens 
Seventy paraffin blocks of brain tissue were collected from the archives of the department of pathology, faculty of medicine, Zagazig university and Teiba lab. In the period from January 2005 to December 2014. Approval is obtained for performing the study and ethical committee in the faculty is put in consideration. The studied specimens included 40 cases of astrocytoma were classified as 5 cases pilocytic astrocytomas WHO I and 10 cases diffuse astrocytomas WHO II, 12 cases anaplastic astrocytomas WHO III, and 13 cases glioblastomas WHO IV. None of the patients received chemotherapy or radiotherapy before biopsy. 30 control samples of non-neoplastic brain tissue included inflammatory, brain edema, normal brain tissue adjacent to cystic lesions or neoplasm. The clinicopathologic data of age, sex, size and site were collected from patient files and reviewed. Consecutive $4 \mu \mathrm{m}$ thick sections from each block was evaluated histopathologically using (H\&E) stain to confirm the diagnosis. Serial sections from the same blocks are submitted for immunohistochemical staining for BMI1 and EZH2. The corresponding hematoxylin and eosin $(\mathrm{H} \& \mathrm{E})$ stained slides of each case were reviewed according to diagnostic criteria of the WHO 2007 Classification of tumors of the Central Nervous System and the 40 cases of astrocytoma were graded according to Louis et al. ${ }^{[1]}$, into astrocytomas WHO grade I and astrocytomas WHO grade II, and astrocytomas WHO grade III, and glioblastomas WHO grade IV.

\section{IMMUNOHISTOCHEMISTRY}

Immunohistochemical stain was carried out using the indirect streptavidin-biotin immunoperoxidase staining technique with the following primary antibodies used were used anti BMI1 rabbit polyclonal antibody (\#ab
219469, 1:200 dilution; USBiological, USA) and Anti EZH2 mouse monoclonal antibody (Clone No. 144CT2.1.1.5, \#ab 030954, 1:50 dilution; USBiological, USA). 30 cases of nonneoplastic brain tissue were used as control. Normal testicular tissue in EZH2 and human breast carcinoma for testing BMI1 were used as positive control. Negative controls were employed using antibody diluent in PBS buffer instead of primary antibodies and subsequently stained with the positive controls. Normal, Positive and negative controls were stained at the same staining setting with the studied cases. The percentage scoring of immunoreactive tumor cells was calculated as follows: $0(0 \%), 1$ $(1-10 \%), 2(11-50 \%)$ and $3(>50 \%)$. The staining intensity was divided into following: 0 (negative), 1 (weak), 2 (moderate) and 3 (strong). According to $\mathrm{Wu}$ et al. ${ }^{\text {[25], final }}$ immunoreactivity scores (IRS) were calculated by multiplying the percentage and the intensity scores for each case then selection the median of IRS for BMI1 or EZH2 expression level cutoff points. This method measured the following values as standards for the high expression group: BMI $1 \geq 6$ and $\mathrm{EZH} 2 \geq 5$.

\section{STATISTICAL ANAL YSIS}

Data was analyzed by Statistical Package of Social Science (SPSS), software version 22.0 (SPSS Inc., 2013). Categorical data (nominal or ordinal data) were presented by the frequency and percentage. The chi-square test of association is used for correlation between two categorical variables. Spearman's correlation is used as a nonparametric measure of the strength and direction of correlation between two variables measured on at least an ordinal scale. Cohen's kappa ( $\kappa)$ : measures agreement for categorical scales when excist two raters. $\mathrm{P} \leq$ 0.05 was considered to indicate significance. 


\section{RESULTS}

Table 1: BMI1 and EZH2 expression in astrocytoma and (Control) samples:

BMI1 IRS expression

Low $(\mathrm{n}, \%)$

High (n, \%)

EZH2 IRS expression

Low $(\mathrm{n}, \%)$

High ( $\mathrm{n}, \%)$

\section{Groups}

Astrocytoma

$17(42.5 \%)$

$23(57.5 \%)$

$21(52.5 \%)$

$19(47.5 \%)$

\section{Control}

$28(93.3 \%)$

$2(6.7 \%)$

$26(86.7 \%)$

$4(13.3 \%)$
$(\mathrm{X} 2)^{*}$

19.29

9.071

0.002

*Chi-square test

Table 2: Associations of BMI1 and EZH2 expression in human astrocytoma tissues with different clinicopathological features:

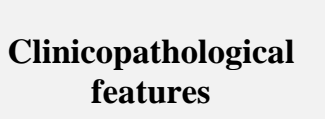

No.
of
cases

BMI1 expression

High Low

$\left(\mathbf{X}^{2}\right)^{*}$

$(\mathrm{N}, \%)$

$(\mathbf{N}, \%)$

$5 \quad 1(20.0 \%) \quad 4(80.0 \%)$

$10 \quad 2(20.0 \%) \quad 8(80.0 \%)$

$12 \quad 9(75.0 \%) \quad 3(25.0 \%)$

$13 \quad 11(84.6 \%) \quad 2(15.4 \%)$

III

IV

\section{Age \\ $\leq 50$ \\ $>50$}

\section{EZH2 expression}

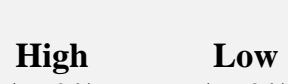

$(\mathbf{n}, \%) \quad(\mathrm{n}, \%)$

$\left(\mathbf{X}^{2}\right) \quad \mathbf{P}$

$0(0.0 \% \quad 5(100.0 \%)$

$\begin{array}{llll}2(20.0 \%) & 8(80.0 \%) & 12.63 & 0.005\end{array}$

$7(58.3 \%) \quad 5(41.7 \%)$

$10(76.9 \%) \quad 3(23.1 \%)$

$\begin{array}{cccc} & & 0(0.0 \% & 5(100.0 \%) \\ 14.047 & 0.003 & 2(20.0 \%) & 8(80.0 \%) \\ & & 7(58.3 \%) & 5(41.7 \%) \\ & & 10(76.9 \%) & 3(23.1 \%)\end{array}$

$1.125 \quad$ NS

$9(40.9 \%)$

$10(55.6 \%)$

$13(59.1 \%)$

$8(44.4 \%)$

0.852 NS

Gender

Male

Female

$$
22 \quad 11(50.0 \%) \quad 11(50.0 \%)
$$

$1.125 \quad$ NS

$11(50.0 \%)$

$8(44.4 \%)$

$11(50.0 \%)$

$10(55.56 \%)$

$0.123 \quad \mathrm{NS}$

Size (cm)

$\leq 5$

$>5$

16

$7(43.75 \%) \quad 9(56.25 \%)$

$16(66.7 \%) \quad 8(33.3 \%)$

2.06

NS

$7(43.75 \%)$

$12(50.0 \%)$

$9(56.25 \%)$

$12(50.0 \%)$

$0.15 \quad$ NS

Site

Supratentorial Infratentorial Intraventricular $\begin{array}{cccc}7.73 \quad \text { NS } & 19(54.3 \%) & 16(45.7 \%) \\ & & 0(00 \%) & 3(100 \%) \\ & 0(00 \%) & 2(100 \%)\end{array}$

$5.17 \quad$ NS

Note: "NS" refers to the difference without statistical significance. 
Table 3: Correlation between BMI1 IRS and EZH2 IRS:

\begin{tabular}{|c|c|c|}
\hline \multicolumn{2}{|c|}{ Variable } & BMI1 IRS \\
\hline \multirow{2}{*}{ EZH2 IRS } & r $^{*}$ & 0.311 \\
\cline { 2 - 3 } & $\mathrm{P}$ & $\mathbf{0 . 0 5}$ \\
\hline
\end{tabular}

*r: Spearman's rho correlation

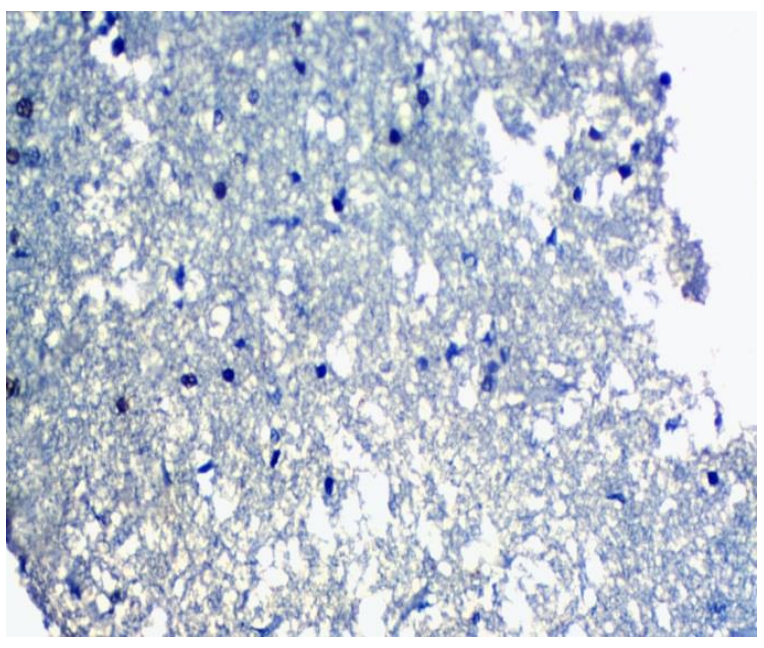

Figure1: normal brain tissue shows negative BMI1 nuclear expression (Immunoperoxidase staining, DAB chromogen, Mayer's hematoxylin counter stain, original magnification $\mathrm{X} 400$ ).

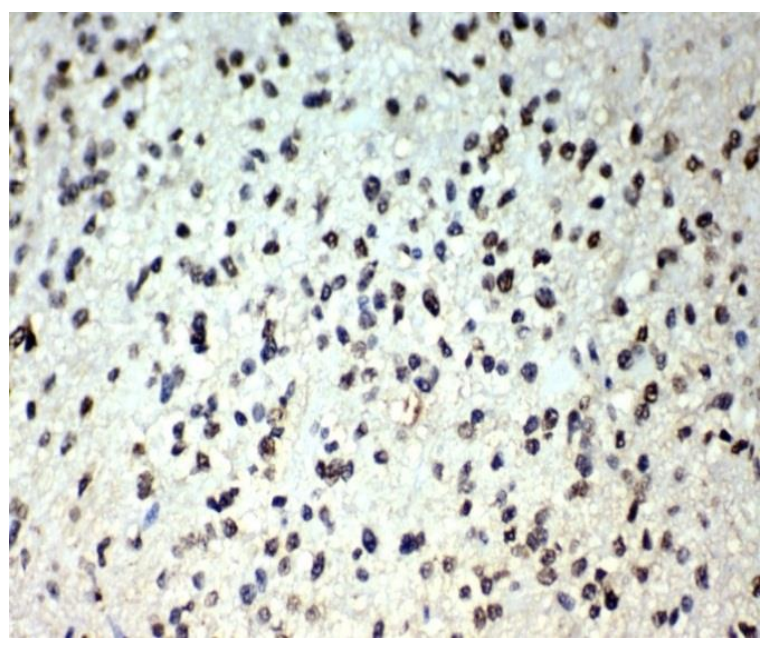

Figure2: grade II astrocytoma shows moderate BMI1 nuclear expression (Immunoperoxidase staining, DAB chromogen, Mayer's hematoxylin counter stain, original magnification $\mathrm{X} 400$ ).

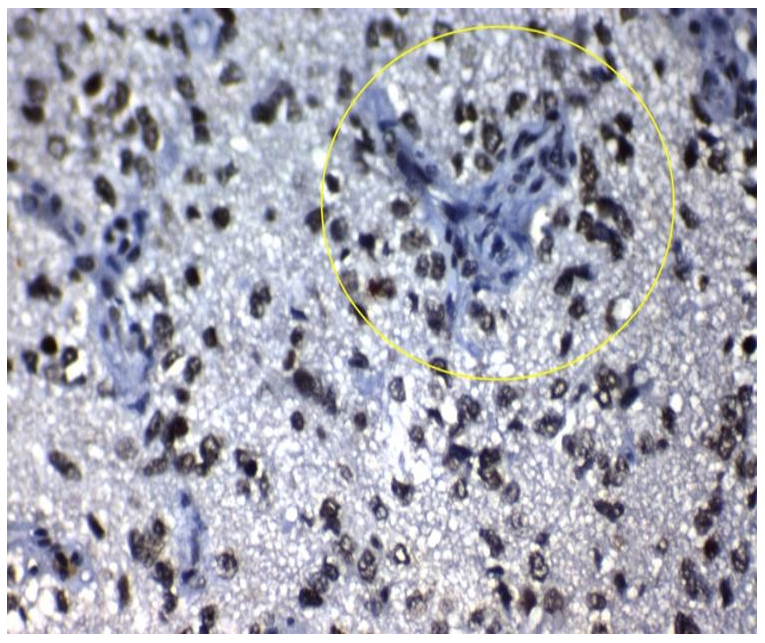

Figure3: grade IV astrocytoma shows strong BMI1 nuclear expression with neoplastic cells concentrated around endothelial proliferations negative BMI1 nuclear expression (yellow circle) (Immunoperoxidase staining, DAB chromogen, Mayer's hematoxylin counter stain, original magnification X400).

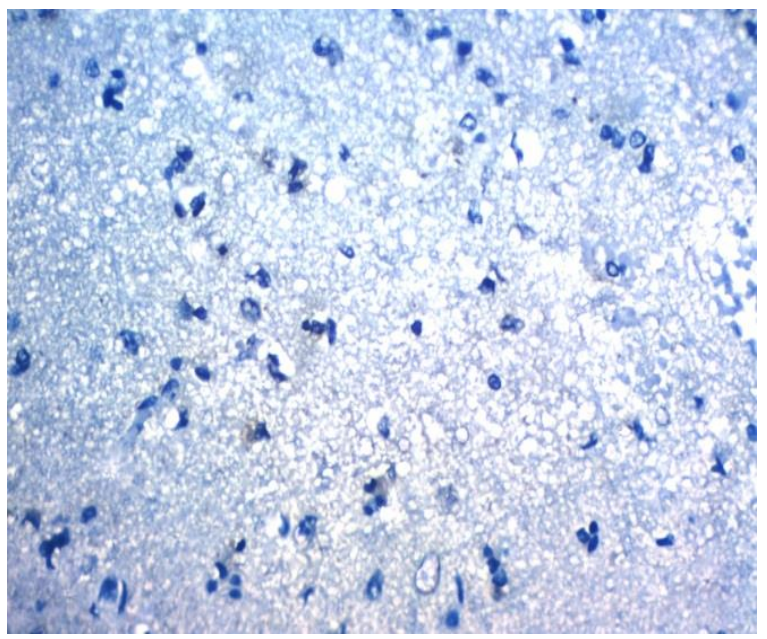

Figure4: non-neoplastic brain tissue shows negative EZH2 nuclear expression (Immunoperoxidase staining, DAB chromogen, Mayer's hematoxylin counter stain, original magnification X400). 


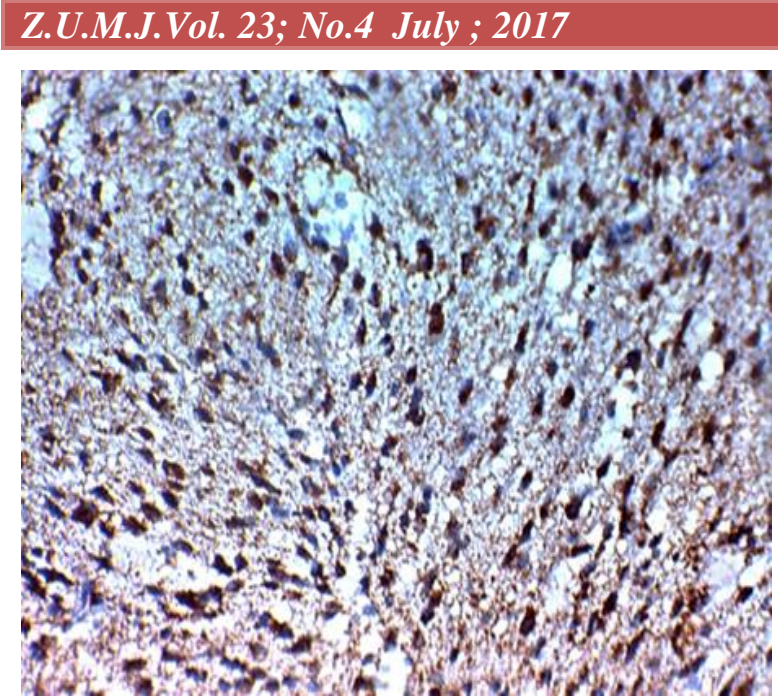

Figure5: grade II astrocytoma shows moderate EZH2 nuclear expression (Immunoperoxidase staining, DAB chromogen, Mayer's hematoxylin counter stain, original magnification X400).

\section{DISCUSSION}

Astrocytic tumors in Egypt constituted about (54.9\%) of all Central Nervous System tumors, in study by national cancer institude (NCI) included 810 cases of CNS tumors. They recorded according to WHO classification, 4th edition 2007, by histology. The most frequently reported malignant CNS neoplasms were fibrillary astrocytomas which accounts for (22.6\%). glioblastoma multiform (GBM), the most aggressive brain neoplasm, alone represented $(14.3 \%)$ of all CNS tumors ${ }^{[26] .}$

GBM is an incurable disease with only 15 months a median survival. Based on the 2013 Central Brain Tumor Registry of the United States (CBTRUS) 2006-2010 report, the average annual incidence rate (IR) of GBM is 3.19 per 100,000 populations. This is the highest incidence rate among CNS tumors with malignant behavior [27]. GBM includes functional groups of cells termed glioblastoma stem-like cells (GSCs), which are radioresistant and chemoresistant and ultimately result in tumor recurrence. Dysregulation of PcG (BMI1 and EZH2) is closely linked to the GSC maintenance and tumorigenicity $\left[{ }^{3}\right]$. This study depends on theory of cancer stem cell prognostic role and aimed at immunohistochemical evaluation of BMI1 and

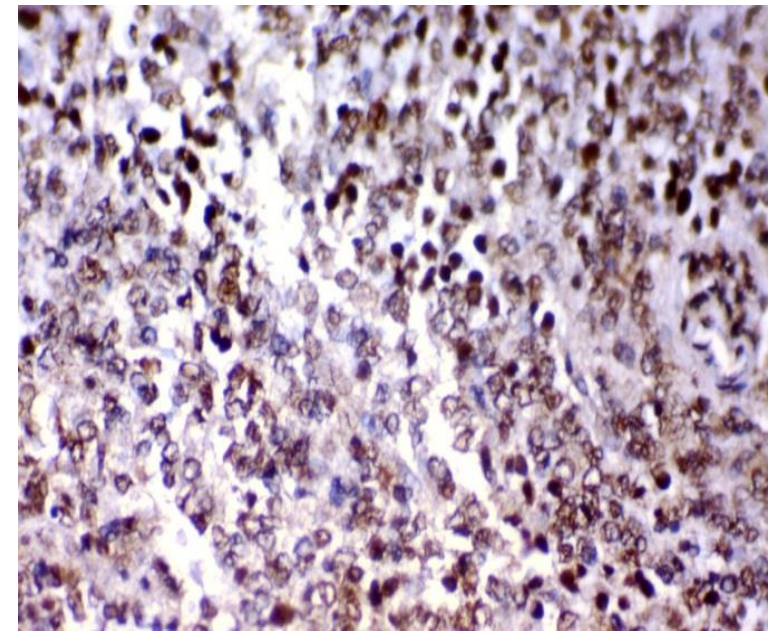

Figure6: grade III astrocytoma shows strong EZH2 nuclear expression (Immunoperoxidase staining, DAB chromogen, Mayer's hematoxylin counter stain, original magnification X400).

EZH2 and their correlation with prognosis and the clinicopathological characters in astrocytoma (particularly in glioblastoma multiform) patients.

\section{BMI1 and EZH2 expression in astrocytoma and non-neoplastic brain tissue:}

Current study demonstrated a highly significant difference $(\mathrm{P}<0.001)$ between BMI1 expression in astrocytoma cases and in non-neoplastic brain tissue (Control) as BMI1 showed high expression (23/40) $(57.5 \%)$ in astrocytoma cases versus only $(2 / 30)(6.7 \%)$ in control. In agreement with our study, $\mathrm{Wu}$ et al. [25], reported that 86 cases $(67.19 \%)$ were regarded as BMI1 group with high expression. The level of BMI1 protein expression was significantly higher in glioma tissues than those in equivalent nonneoplastic brain tissues $(\mathrm{P}<$ 0.001). With regard to involvement of BMI1 in tumor progression, several reports have employed by Bruggeman et al. [28], who concluded that BMI1 has been implicated in the pathogenesis of brain tumors such as gliomas.

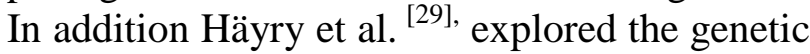
status and the correspondent expression patterns of BMI1 in a series of 100 low- and high-grade primary and recurrent gliomas suggesting that BMI1 possibly contributes to brain tumor pathogenesis. 
Also current study demonstrated a highly significant difference $(\mathrm{P}=0.002)$ between EZH2 expression in astrocytoma cases and in nonneoplastic brain tissue (Control) as EZH2 showed high expression (19/40) (47.5\%) in astrocytoma cases versus only (4/30) (13.3\%) in control. As regard EZH2 role in tumor development, our results supported by similar reports by $\mathrm{Wu}$ et al. who investigated that 80 cases $(62.50 \%)$ that have EZH2 high expression level were significantly higher in glioma tissues than those in equivalent nonneoplastic brain tissues $(\mathrm{P}<0.001)$. In addition Ding and Kleer [30], concluded that increased expression of EZH2 in normal breast tissue disposes to subsequent development of cancer, also similar results by Zhang et al. ${ }^{[24]}$, and Ahani et al. ${ }^{[31] .}$ In glioblastomas, who demonstrated that EZH2 inhibited differentiation and activated genes, regulating cell cycle progression, cell proliferation and cell migration.

So our study demonstrated that the deregulation of BMI1and EZH2 correlating with astrocytoma development and pathogenesis. Our results matched with Abdouh et al. ${ }^{[32]}$, who shown that BMI1 and EZH2 were related to GBM tumor growth and needed to maintain renewal of cancer initiating stem cell.

\section{BMI1 and EZH2 expression with clinicopathological features of astrocytoma:}

This study proved a highly significant association $(\mathrm{P}=0.003)$ between low expression of BMI1 and low grades (grade I\& grade II) as $(80 \%)$ of the cases show low expression, also, a statistically significant association was found between high expression of BMI1 and high grades (grade III \& glioblastoma) with percentage of $(75.0 \%) \&(84.6 \%)$ respectively. Several reports varied in explaining BMI1correlation to tumor grade and prognosis. Our results agreed with $\mathrm{Wu}$ et al. ${ }^{[25]}$, who reported that upregulation of BMI1 was significantly correlated with advanced WHO grades $(\mathrm{P}<0.001)$ and concluded that BMI expression $(\mathrm{P}=0.008)$ was poor prognostic factor in glioma patients. In addition Farivar et al. [33], also concluded that BMI1 high expression is correlated with lower survival and could be used as a strong molecular marker of prognosis in pediatric brain tumors.

In contrary to other studies by Cenci et al. ${ }^{[34]}$, who revealed that BMI1 high expression was favourable for the patient survival contributed that to possible proapoptotic role of BMI1 protein in primary glioblastoma. On the other hand, Wei et al. ${ }^{[35],}$ explained the unpredictable relationship between BMI1 expression and the prognosis to its role in DNA repair. Acceptable

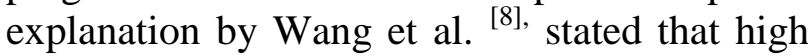
level of BMI1 expression was dependent on the cell type and not necessary to associate with a poor prognosis for all types of cancer. For example, high levels of BMI1 were related to a better overall survival in patients with breast cancer, malignant melanoma and endometrial carcinomas. Therefore, these results are necessaryy to be considered when developing targeted new plans for therapy. In current study, there was a significant association $(\mathrm{P}=0.005)$ between low expression of EZH2 and low grades (grade I\& grade II) with percentage of $(100.0 \%) \&(80.0 \%)$ respectively, also, a significant association between high expression of EZH2 and high grades (grade III \& glioblastoma) as $(58.3 \%)$ \& $(76.9 \%)$ respectively, suggesting relation to tumor aggressiveness. Many studies demonstrated this EZH2 relation to tumor aggressiveness; according to $\mathrm{Wu}$ et al. [25], study showed upregulation of EZH2 protein was significantly associated $(\mathrm{P}<0.001)$ with advanced WHO grades in glioma patients and concluded that expression of BMI1 and EZH2 $(\mathrm{P}=0.008)$, were prognostic factors for overall survival in glioma patients. In addition Wang et al. [8], revealed that EZH2 expression correlated with tumor aggressiveness across all cancer types and $\mathrm{Li}$ et al. [36], showed that the most frequently overexpressed $\mathrm{PcG}$ gene in GBMs was EZH2 in (98.6\%) and suggested that EZH2 a hopeful therapeutic target in GBMs because of the extremely high frequency of overexpression. Also similar results were optained by Suvà et al. ${ }^{[37]}$ and Orzan et al. ${ }^{\text {[38]. }}$ As regard other clinicopathologic characteristics of astrocytoma (age at diagnosis, 
gender of patients, site and size of tumor), the current study found no statistically significant association $(\mathrm{P}>0.05)$ with BMI1or EZH2. Our results agreed with $\mathrm{Wu}$ et al. ${ }^{[25],}$ who concluded no statistically significant association of with age at diagnosis and gender of patients was found.

Finally the current study showed that expressions of BMI1 and EZH2 were correlated positively with the astrocytoma grades, suggested that both were considered as poor prognostic factors. This was agreement with $\mathrm{Wu}$ et al. ${ }^{[25]}$, who prove that expression of BMI1 and EZH2 $(\mathrm{P}=0.008)$, were prognostic factors for overall survival in glioma patients.

\section{Association between BMI and EZH2 expression:}

The current study showed a significant $(\mathrm{P}=$ 0.049) overall a fair agreement between the results of BMI1 and EZH2 expression was $(65 \%)$, with kappa $(\kappa)=0.305$. The spearman correlation analysis showed a significant positive correlation between BMI1 expression and EZH2 expression $(\mathrm{r}=0.311 ; \mathrm{P}=0.05)$ revealing direct relationship between BMI1 and EZH2. These results supported by one study of $\mathrm{Wu}$ et al. ${ }^{[25],}$ proved such correlation between BMI1 and EZH2 overexpression in gliomas with spearman correlation analysis $(\mathrm{r}=0.56$; $\mathrm{P}$ $<0.001$ ). In addition Hyland et al. [39], established that EZH2 may be one of the PcG proteins essential for BMI1 recruitment to the PcG bodies, suggesting the closed relationship between BMI1 and EZH2

\section{CONCLUSION}

Deregulations of BMI1 and EZH2 have a role in astrocytoma development and pathogenesis, revealed higher expression in astrocytomas compared to non-neoplastic brain tissue. BMI1 and EZH2 are considered poor prognostic factors in astrocytoma depending on their positive correlation with the astrocytoma grades. No statistically significant association between the clinicopathologic characteristics of astrocytoma (age at diagnosis, gender of patients, site and size of tumor) and BMI1or EZH2 expression. There is a positive correlation between BMI1 expression and
EZH2 expression in astrocytoma. In the future, BMI1 and EZH2 will be considered as promising therapeutic targets in GBMs.

\section{REFERENCES}

[1]. Louis D, Ohgaki H, Wiestler O, Cavenee W, Burger P, Jouvet A et al. The 2007 WHO classification of tumours of the central nervous system. Acta Neuropathol 2007; 114(2): 97-109.

[2]. Zhang $X$, Yang $H$, Gong $B$, Jiang $C$ and Yang L. Combined gene expression and protein in-teraction analysis of dynamic modularity in glioma prognosis. J Neurooncol 2012; 107:2818.

[3]. Yi Y, Hsieh I, Huang X, Li J and Zhao W. Glioblastoma Stem-Like Cells: Characteristics, Microenvironment, and Therapy. Front Pharmacol 2016; 7:477.

[4]. Hira V, Ploegmakers K, Grevers F, Verbovšek U, Silvestre-Roig $\mathbf{C}$, Aronica E, et al."CD133+ and Nestin+ Glioma Stem-Like Cells Reside Around CD31+ Arterioles in Niches that Express SDF-1 $\alpha$, CXCR4, Osteopontin and Cathepsin K". J Histochem Cytochem. 2015; 63(7):481-93.

[5]. Levine S, King I and Kingston R. Division of labor in pol Surface ycomb group repression. Trends Biochem Sci 2004; 29(9):478-485.

[6]. Schuettengruber $B$ and Cavalli G. Recruitment of polycomb group complexes and their role in the dynamic regulation of cell fate choice. Development 2009; 136(21):3531-3542.

[7]. Richly H, Aloia L and Di Croce L. Roles of the Polycomb group proteins in stem cells and cancer. Cell Death Dis 2011; 2:e204.

[8]. Wang W, Qin J, Voruganti S, Nag S, Zhou J and Zhang R. Polycomb Group (PcG) Proteins and Human Cancers: Multifaceted Functions and Therapeutic Implications. Med Res Rev 2015; 35(6):1220-67.

[9]. Zhang M, Wang Y, Jones S, Sausen M, McMahon K, Sharma $R$ et al. Somatic mutations of SUZ12 in malignant peripheral nerve sheath tumors. Nat Genet 2014; 46(11):1170-1172.

[10]. Chen B, Liu J, Chang Q, Beezhold K, Lu Y and Chen F. JNK and STAT3 signaling pathways converge on Akt-mediated phosphorylation of EZH2 in bronchial epithelial cells induced by arsenic. Cell Cycle 2013; 12(1):112-121.

[11]. Zeidler M, Varambally S, Cao Q, Chinnaiyan A, Ferguson D, Merajver $S$ et al. 
The Polycomb group protein EZH2 impairs DNA repair in breast epithelial cells. Neoplasia 2005; 7(11):1011-1019.

[12]. Shakhova O, Leung $\mathbf{C}$ and Marino S. Bmi1 in development and tumorigenesis of the central nervous system. J Mol Med 2005; 83 (8): 596600.

[13]. Gil J and Peters G. Regulation of the INK4bARF-INK4a tumour suppressor locus: all for one or one for all. Nat Rev Mol Cell Biol 2006; 7(9):667-677.

[14]. Crea F, Clermont P, Mai A and Helgason C. Histone modifications, stem cells and prostate cancer. Curr Pharm Des 2014; 20(11):16871697. 259.

[15]. Allegra E, Trapasso S, Pisani D and Puzzo

L. The role of BMI1 as a biomarker of cancer stem cells in head and neck cancer: a review. Oncology 2014; 86(4):199-205.

[16]. Proctor E, Waghray M, Lee C, Heidt D, Yalamanchili $\mathbf{M}, \mathbf{L i} \mathbf{C}$, et al. Bmi 1 enhances tumorigenicity and cancer stem cell function in pancreatic adenocarcinoma. PloS One 2013; 8(2): 555820.

[17]. Tateishi K, Ohta M, Kanai F, Guleng B, Tanaka Y, Asaoka Y, et al. Dysregulated expression of stem cell factor Bmi1 in precancerous lesions of the gastrointestinal tract. Clin Cancer Res 2006; 12(23):6960-6966.

[18]. Kang M, Kim R, Kim S, Yip F, Shin K, Dimri G, et al. Elevated Bmi-1 expression is associated with dysplastic cell transformation during oral carcinogenesis and is required for cancer cell replication and survival. Br J Cancer 2007; 96(1):126-133.

[19]. Kozakowski N, Soleiman A and Pammer J. BMI-1 expression is inversely correlated with the grading of renal clear cell carcinoma. Pathol Oncol Res 2008; 14(1):9-13.

[20]. Konze K, Ma A, Li F, Barsyte-Lovejoy D, Parton T, Macnevin C, et al. "An orally bioavailable chemical probe of the Lysine Methyltransferases EZH2 and EZH1". ACS Chem Biol 2013; 8 (6): 1324-34.

[21]. Yoo K and Hennighausen L. "EZH2 methyltransferase and $\mathrm{H} 3 \mathrm{~K} 27$ methylation in breast cancer". Int J Biol Sci 2012; 8 (1): 59-65.

[22]. Saramaki O, Tammela T, Martikainen P, Vessella $R$ and Visakorpi T. The gene for polycomb group protein enhancer of zeste homolog $2(\mathrm{EZH} 2)$ is amplified in late-stage prostate cancer. Genes Chromosomes Cancer 2006; 45(7):639-645.

[23]. Morin R, Johnson N, Severson T, Mungall A, An J, Goya R, et al. Somatic mutations altering EZH2 (Tyr641) in follicular and diffuse large B-cell lymphomas of germinal-center origin. Nat Genet 2010; 42(2):181-185.

[24]. Zhang J, Chen L, Han L, Shi Z, Zhang J, Pu P, et al. EZH2 is a negative prognostic factor and exhibits pro-oncogenic activity in glioblastom. Cancer Lett 2015; 356(2 Pt B):929936.

[25]. Wu Z, Wang Q, Wang L, Li G, Liu H, Fan F, et al. Combined aberrant expression of Bmi1 and EZH2 is predictive of poor prognosis in glioma patients. J Neurol Sci. 2013; 335(12):191-6.

[26]. Mokhtar N, Salama A, Badawy O, Khorshed E, Mohamed G, Ibrahim M, et al. Cancer Pathology Registry A 12-year Registry 2000 - 2011. National Cancer Institute 2016; 13: 192-208.

[27]. Thakkar J, Dolecek T, Horbinski C, Ostrom Q, Lightner D, Barnholtz-Sloan J, et al. Epidemiologic and Molecular Prognostic Review of Glioblastoma. Cancer Epidemiol Biomarkers Prev 2014; 23(10): 1985-1996.

[28]. Bruggeman S, Hulsman D, Tanger E, Buckle T, Blom M, Zevenhoven J, et al. Bmi 1 controls tumor development in an Ink4a/Arfindependent manner in a mouse model for glioma. Cancer Cell 2007; 12(4):328-41.

[29]. Häyry V, Tanner M, Blom T, Tynninen O, Roselli A, Ollikainen M, et al. Copy number alterations of the polycomb gene BMI in gliomas. Acta Neuropathol 2008; 116:97-102.

[30]. Ding L and Kleer C. Enhancer of Zeste 2 as a marker of preneoplastic progression in the breast. Cancer Res. 2006; 66(19):9352-9355

[31]. Ahani N, Shirkoohi R, Rokouei M, Alipour Eskandani $M$ and Nikravesh $A$. Overexpression of enhancer of zeste human homolog 2 (EZH2) gene in human cytomegalovirus positive glioblastoma multiforme tissues. Med Oncol. 2014; 31(11):252.

[32]. Abdouh M, Facchino S, Chatoo W, Balasingam V, Ferreira $J$ and Bernier $G$. BMI1 sustains human glioblastoma multiforme stem cell renewal. J Neurosci. 2009; 29:88848896. 
[33]. Farivar S, Zati-Keikha R, Shiari $\mathbf{R}$ and Jadali F. Expression of bmi-1 in pediatric brain tumors as a new independent prognostic marker of patient survival. Biomed Res Int. 2013; 2013:192548.

[34]. Cenci T, Martini M, Montano N, D'Alessandris Q, Falchetti M, Annibali D et al. Prognostic relevance of C-MYC and BMI1 expression in patients with glioblastoma. Am. J. Clin Pathol 2012; 138, 390-396.

[35]. Wei F, Ojo D, Lin X, Wong N, He L, Yan J, et al. BMI1 attenuates etoposide-induced G2/M checkpoints via reducing ATM activation. Oncogene 2015; 34(23):3063-75.

[36]. Li G, Warden C, Zou Z, Neman J, Krueger J, Jain A, et al. Altered Expression of Polycomb Group Genes in Glioblastoma Multiforme. PLoS One 2013; 8(11):e80970.
[37]. Suvà M, Riggi N, Janiszewska M, Radovanovic I, Provero $P$, Stehle $J$, et al. $\mathrm{EZH} 2$ is essential for glioblastoma cancer stem cell maintenance. Cancer Res 2009; 69(24):9211-8.

[38]. Orzan F, Pellegatta S, Poliani P, Pisati F, Caldera V, Menghi F, et al. Enhancer of Zeste 2 (EZH2) is up-regulated in malignant gliomas and in glioma stem-like cells. Neuropathol Appl Neurobiol 2011; 37(4):381-94.

[39]. Hyland P, McDade S, McCloskey R, Dickson G , Arthur K, McCance D , et al. Evidence for alteration of EZH2, BMI1, and KDM6A and epigenetic reprogramming in human papillomavirus type 16 E6/E7-expressing keratinocytes. J Virol 2011; 85(21):10999-1006. 


\section{القيمة التكهنية للإظهار المناعى الهستوكيميائى المشترك JBMI1 وEZH2 فى أورام الخلايا النجمية}

بـالرغم مـن التطور ات الحديثة في الجر احـة، و العـلاج الإشـعاعي ، و الكيميائي ، إلا أن متوسط بقـاء مرضسى الأورام النجميـة لايز ال ضعيفاو لم بطر أ تغيير كبير على مدى عقد التهد. وبالتالي، فمن الضروري أن نفهم الخلفية الجينية و العمليات الجزيئية المسبية لهذه الأورام من أجل الكثف عن الآليات الكامنة ور اء بدءء و تطور المرض ، وفتح أبواب جديدة لتطوير الاستر اتيجيات التشخيصية و العلاجية. مجمو عة البروتينات (Polycomb (PCG) ، تلعب دورا هاما في تنظيم مختلف العمليات الفسيولوجية و المرضية ، بما في ذللك تكون

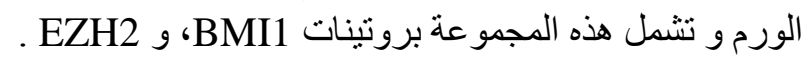

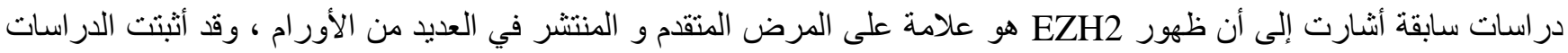

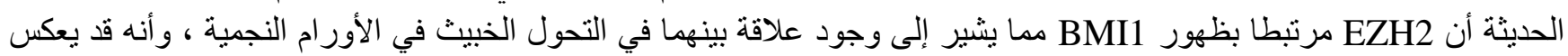
أيضا العدو انية البيولوجية لهذا المرض. تهدف الرسالة إلي تقييم إظهار BMI1 و EZH2 بالطرق المناعية النسيجية الكيميائية في حالات الأورام النجمية ومقارنتها بالعو امل السريرية و النسيجية. شملت الدر اسه الحاليه تجميع سبعون حالة أرشيفية منهم اربعون حاله للأور ام النجميه وثناثون حاله اخرى لنسيج المخ غبر الورمى،

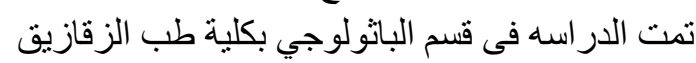

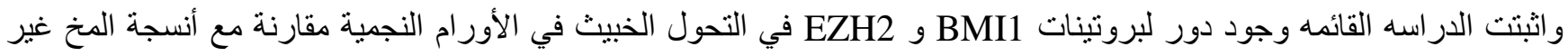

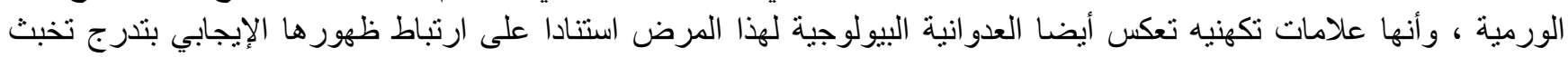
الورم. بينما استنتجت الدر اسه الحاليه عدم وجود ارتباط ذو دلالة إحصائية بين (العمر عند النتخيص، وجنس المرضى، وموقع وحجم الورم)

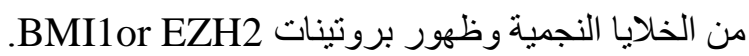
اثشارت الدر اسه القائمه ان هناك علاقة طرديا بين ظهور بروتينات BMI1 و BZH2 يستخلص منه ارتباطهما ببعضهها فى دور هم فى اور ام الخلايا النجمية. اوصت الدر اسه اعتبار BMI1 و EZH2 أهداريا الجما علاجية في المستقبل. 